\title{
Intracerebral Hemorrhage due to Metastasis of Ovarian Granulosa Cell Carcinoma 36 Years after Initial Diagnosis
}

\author{
Josef G. Heckmann ${ }^{a} \quad$ Christian Tilz $^{\mathrm{a}}$ Matthias Dütsch ${ }^{\mathrm{a}}$ Ingmar Blümcke ${ }^{\mathrm{b}}$ \\ Michelle Hildebrandt ${ }^{\mathrm{b}}$ Stefan Schwab ${ }^{\mathrm{a}}$ \\ Departments of ${ }^{\mathrm{a}}$ Neurology and ${ }^{\mathrm{b}}$ Neuropathology, University Hospital Erlangen, Erlangen, Germany
}

Dear Sir,

Ovarian cancer is the fifth most frequent cancer in women, with poor prognosis if diagnosed at an advanced stage [1]. Metastasis to the central nervous system is a rare condition $(0.5-0.9 \%)$ that is ascribed to the double capillary filter of the liver and lung [1-4]. Granulosa cell tumors are malignant sex-cord-stromal tumors and account for $2-3 \%$ of all ovarian tumors. Their natural history is characterized by slow growth and late recurrence occurring at a mean interval of 6 years after the initial diagnosis [5].

In the etiology of spontaneous intracerebral hemorrhages (ICHs), intracranial tumors play a not negligible role. In a large analysis from a single center, $4.4 \%$ of intracerebral hematomas were related to intracranial tumors, mostly glioblastoma, metastases, anaplastic and low-grade glioma, and meningiomas [6]. In other cohorts, $1.4-15 \%$ of spontaneous ICHs are tumorassociated depending on the age of patients and the different diagnostic procedures [7]. We report a patient with acute $\mathrm{ICH}$ due to metastasis of a granulosa cell carcinoma with symptomatic bleeding. Hitherto, in the literature there have been descriptions of 3 patients with solitary intracranial metastases of a granulosa cell carcinoma $[4,8]$. In our patient, the primary manifestation of the ovarian granulosa cell carcinoma had been surgically treated 36 years earlier. The patient remained in a state of complete clinical re- mission until the occurrence of the cerebral hemorrhage.

A 69-year-old woman reported acute headache, vomiting and blurred vision. Clinical examination showed a homonymous hemianopia to the right side and somnolence. At this time, cranial computed tomography demonstrated an atypically located intracranial hemorrhage in the left parieto-occipital region (fig. 1).

As somnolence rapidly progressed, intubation and mechanical ventilation were initiated and surgical treatment performed. The lesion was completely resected. Microscopic investigation revealed a malignant epitheloid tumor with a hepatiform growth pattern and the presence of so-called 'coffee-bean' nuclei. Immunoreactivity for inhibin and CD99 in the majority of tumor cells confirmed the diagnosis of granulosa cell carcinoma (fig. 2).

The postoperative course was uneventful. Additional gynecological examination showed no further local recurrence of granulosa cell carcinoma. PET examination, performed to detect neoplastic tissue, was unremarkable except for a diminished allocation of the nuclide in the left parietooccipital brain region. Whole brain radiation therapy with 40 Gy was performed.

Clinical and neuroradiological followup 6 months after diagnosis showed no signs of cranial and extracranial tumor recurrence.

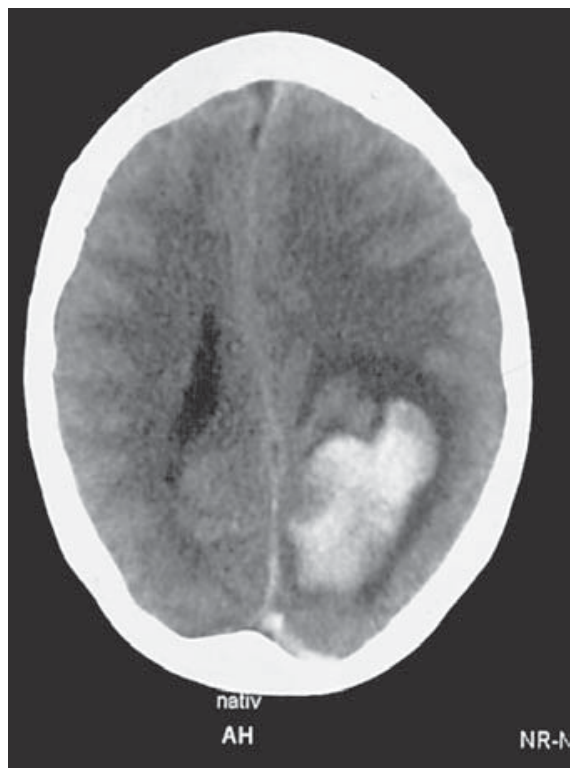

Fig. 1. CT scan showed an atypical lobar hemorrhage in the left parieto-occipital region.

We would like to emphasize two important aspects of this case. Firstly, brain tumor bleeding is mostly related to highly vascularized and rapidly growing tumors with an imbalance of blood supply to the tumor resulting in necrosis and bleeding. A further potential bleeding cause is inva-

\section{KARGER}

Fax +4161306 1234 E-Mail karger@karger.ch www.karger.com
(C) 2007 S. Karger AG, Basel 0014-3022/07/0582-0114\$23.50/0

Accessible online at: www.karger.com/ene
Dr. Josef G. Heckmann

Department of Neurology, University Hospital Erlangen

Schwabachanlage 6, DE-91054 Erlangen (Germany)

Tel. +49 9131853 3001, Fax +4991318534436

E-Mail josef.heckmann@neuro.imed.uni-erlangen.de 

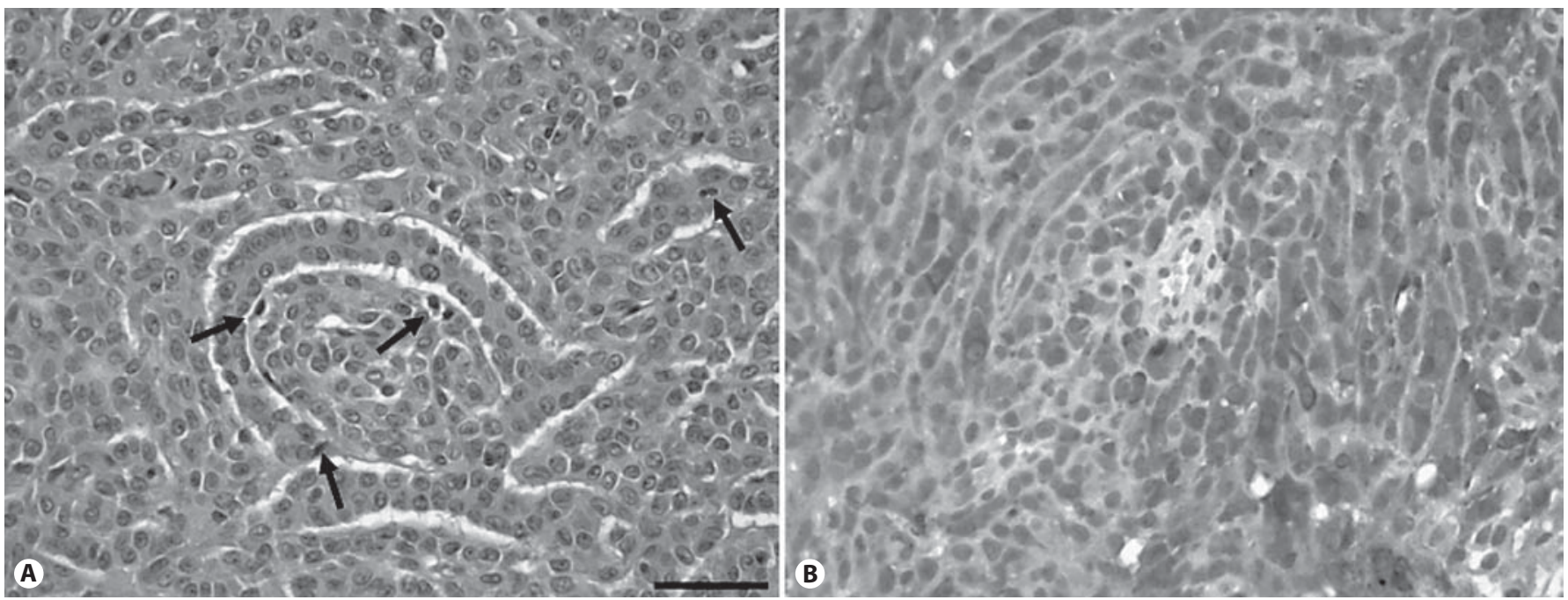

Fig. 2. A Microscopic investigation showing a hepatiform growth pattern and the presence of 'coffee-bean' nuclei (arrows). HE. $\times 200$. Bar $=50 \mu \mathrm{m}$ (refers also to B). B Immunoreactivity for inhibin confirms the diagnosis. Inhibin. $\times 200$.

sion of the tumor into normal vessels. Pathologically, gliomas, meningiomas and metastatic tumors are mostly encountered. Metastatic tumors include lung cancer, liver cancer, breast cancer, renal cell carcinoma, melanoma and different other cancer types [7]. Even rare tumor types can manifest with bleeding such as metastasis of granulosa cell carcinoma as in our case. One factor predisposing to bleeding in granulosa cell carcinomas may be that this tumor type is usually highly vascularized. Also, clinical gynecological manifestation occurs in about $10 \%$ as bleeding [9]. However, the hitherto existing reports on cerebral metastasis of granulosa cell tumor have not described an acute onset with hemorrhage but slowly progressing neurological deficits. In one macroscopic tumor tissue, however, cystic and hemorrhagic changes had been seen [4].

Secondly, despite the known late recurrence of ovarian granulosa cell carcinoma, the time of relapse 36 years after initial diagnosis is quite uncommon $[9,10]$. The mean time for recurrence is 6 years, more than one third occur after 5 years and a 5 th after more than 10 years $[5,8,9]$. In the literature, the latest reported case of recurrence for this tumor type was 37 years after initial diagnosis [11].

To conclude, it has proven necessary to classify spontaneous ICH into primary $\mathrm{ICH}$ due to rupture of small vessels dam- aged by chronic hypertension or amyloid angiopathy, and secondary ICH with defined underlying causes such as vascular malformations, coagulopathy, tumors and other causes [12]. Primary ICHs account for the majority of cases (about 80\%) and its treatment is still a matter of debate. Secondary ICHs occur much less frequently, however should be accurately diagnosed because of the high risk of recurrent hemorrhage and available treatment options [12]. If secondary spontaneous hemorrhage due to the tumor is assumed, even metastasis of long backdated earlier cancer disease such as ovarian granulosa cell tumor should be considered.

\section{References}

1 Cohen ZR, Suki D, Weinberg JS, Marmor E, Lang FF: Brain metastases in patients with ovarian carcinoma: prognostic factors and outcome. J Neurooncol 2004;66:313-325.

2 Gavrilovic IT, Posner JB: Brain metastases: epidemiology and pathophysiology. J Neurooncol 2005;75:5-14.

3 Ziegler J, Gliedman P, Fass D, Beckman M, Neophytides A, Steinfeld A: Brain metastases from ovarian cancer. J Neurooncol 1987; 5:211-215.

4 Ebel H, Villagran R, Conzen M, Schnabel R, Oppel F: Solitäre intrakranielle Spätmetastase eines Granulosazelltumors des Ovar Fallbericht und Literaturübersicht. Neurochirurgia 1993;36:131-134.
5 Segal R, De Petrillo AD, Thomas G: Clinical review of adult granulosa cell tumors of the ovary. Gynecol Oncol 1995;56:338-344.

6 Licata B, Turazzi S: Bleeding cerebral neoplasms with symptomatic hematoma. J Neurosurg Sci 2003;47:201-210.

7 Yuguang L, Meng L, Shugan Z, Yuquan J, Gang L, Xingang L, Chengyuan W: Intracranial tumoural haemorrhage - a report of 58 cases. J Clin Neurosci 2002;9:637-639.

8 Schnittger C, Soudah B, von Wasielewski R, de Groot M, Haubitz B, Becker H, Dengler R: Infiltration of the central nervous system by a granulosa cell tumor immunostained by antibodies against inhibin. Neurology 1998; 50:560-562.

9 Crew KD, Cohen MH, Smith DH, Tiersten AD, Feirt NM, Hershman DL: Long natural history of recurrent granulosa cell tumor of the ovary 23 years after initial diagnosis: a case report and review of the literature. Gynecol Oncol 2005;96:235-240.

10 Lee WL, Yuan CC, Lai CR, Wang PH: Hemoperitoneum is an initial presentation of recurrent granulosa cell tumors of the ovary. Jpn J Clin Oncol 1999;29:509-512.

11 Hines JF, Khalifa MA, Moore JL, Fine KP, Lage JM, Barnes WA: Recurrent granulosa cell tumor of the ovary 37 years after initial diagnosis: a case report and review of the literature. Gynecol Oncol 1996;60:484-488.

12 Qureshi AI, Tuhrim S, Broderick JP, Batjer $\mathrm{HH}$, Hondo H, Hanley DF: Spontaneous intracerebral hemorrhage. N Engl J Med 2001; $344: 1450-1460$. 